Проведено моделирование эволюции нуклидного состава на протяжении 2-х лет работы с периодом переработки растворимых и нерастворимых продуктов деления равным 73 дням. После 73-х дней работы реактора 7 \% топливной соли извлекалось для последующей выдержки и переработки. Взамен в активную зону добавлялась соль исходного состава до достижения критичности системы, далее реактор работал 73 дня на полной мощности, и процесс повторялся вновь. Показано изменение изотопного состава плутония и определение времени выхода реактора на стационар.

На основе проведённых исследований были сделаны выводы о необходимости дальнейшего продолжения работ по развитию предложенной концепции и проработке компоновки реакторной установки.

1. Victor Ignatiev, Olga Feynberg, Progress in Development of Li,Be,Na/F Molten Salt Actinide Recycler and Transmuter Concept, Proceedings of ICAPP (2007).

2. Кандиев Я.З., Оценка эффектов малых возмущений в многовариантных расчётах по программе ПРИЗМА-Д, Атомная энергия, 99, 203 - 210 (2005).

3. Модестов Д.Г. Решение уравнений радиоактивного распада, Вопросы атомной науки и техники, Сер. Математическое моделирование физических процессов (2006).

\title{
ELECTROCHEMICAL PROPERTIES OF MOLYBDENUM IN ALKALI CHLORIDE MELTS
}

\author{
Ivanov A.B. ${ }^{{ }^{*}}$, Volkovich V.A. ${ }^{1}$, Likhachev P.Y. ${ }^{1}$, Griffiths T.R. ${ }^{2}$ \\ ${ }^{1)}$ Ural Federal University named after the first President of Russia \\ B.N.Yeltsin, Yekaterinburg, Russia \\ ${ }^{2)}$ Trevor Redston Consulting, Ltd., Leeds, United Kingdom \\ "E-mail: CHUVASCH@yandex.ru
}

Fused chlorides can be employed as working media for molybdenum electrorefining and for depositing molybdenum coatings. Existing literature contains limited data on the electrode potentials of molybdenum in alkali chloride based melts [1-3]. In the present work electrode potentials of molybdenum were determined in the melts based on individual alkali chlorides $(\mathrm{LiCl}, \mathrm{NaCl}, \mathrm{KCl}, \mathrm{RbCl}, \mathrm{CsCl}),(\mathrm{Na}-\mathrm{K}) \mathrm{Cl}$ equimolar mixture and (Na-Cs)Cl and ( $\mathrm{Li}-\mathrm{K}-\mathrm{Cs}) \mathrm{Cl}$ eutectics.

The measurements were performed using the emf method. The potentials were measured at zero current vs. silver chloride reference electrode. The system was considered at equilibrium if the potential remained constant within $\pm 0.5 \mathrm{mV}$ and did not show the tendency to a monotonous change. Molybdenum ions were introduced to the melt by anodic dissolution of the metal or by dissolving potassium hexachloromo- 
lybdate(III). Molybdenum concentration in the melt was determined by chemical analysis after each experiment.

On the results of the experiments the formal standard electrode potentials of molybdenum were determined in fused $(\mathrm{Li}-\mathrm{K}-\mathrm{Cs}) \mathrm{Cl},(\mathrm{Na}-\mathrm{K}) \mathrm{Cl},(\mathrm{Na}-\mathrm{Cs}) \mathrm{Cl}, \mathrm{LiCl}, \mathrm{NaCl}$, $\mathrm{KCl}, \mathrm{RbCl}$ and $\mathrm{CsCl}$. The results obtained are shown in Fig. 1.

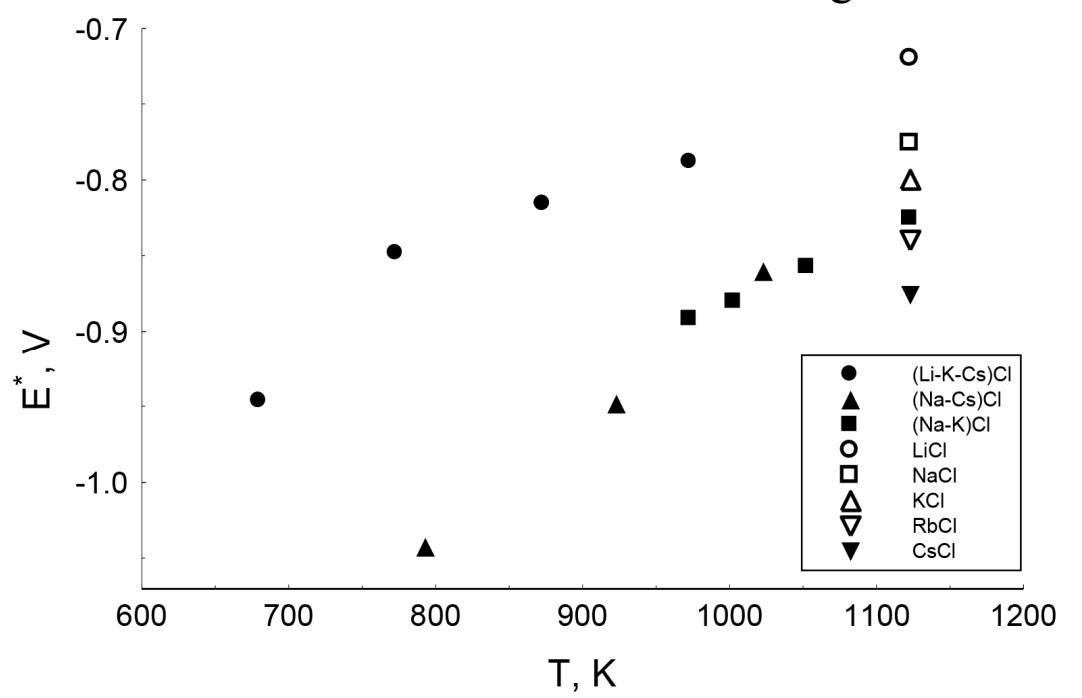

Fig. 1. Molybdenum formal standard elecrode potentials in fused alkali chlorides. Melt composition given for each set of data.

Temperature dependencies of molybdenum formal electrode potential (obtained by the least squares fit) are described by the following equations:

$$
\begin{array}{ll}
E^{*}{ }_{M o 3+/ M o}=\left(-1,727+9,0 \cdot 10^{-4} T\right) \mathrm{V} & (\mathrm{NaCl}-\mathrm{CsCl}) \mathrm{T}=793-1023 \mathrm{~K} \\
E_{M o 3+/ M o}^{*}=\left(-1,327+4,0 \cdot 10^{-4} \mathrm{~T}\right) \mathrm{V} & (\mathrm{NaCl}-\mathrm{KCl}) \mathrm{T}=973-1123 \mathrm{~K} \\
E_{\text {Mo3+/Mo }}^{*}=\left(-1,274+5,0 \cdot 10^{-4} T\right) \mathrm{V} & (\mathrm{LiCl}-\mathrm{KCl}-\mathrm{CsCl}) \mathrm{T}=680-973 \mathrm{~K}
\end{array}
$$

From the results of emf measurements in individual alkali chlorides $(\mathrm{LiCl}, \mathrm{NaCl}$, $\mathrm{KCl}, \mathrm{RbCl}, \mathrm{CsCl}$ ) the following dependence of molybdenum formal electrode potential on radius of alkali metal cation was obtained at $1123 \mathrm{~K}$ :

$E_{M o 3+/ M o}^{*}=(0,2387 \div r-1,0198) \pm 3 \cdot 10^{-2} \mathrm{~V}$

Gibbs free energy change of the formation of molybdenum trichloride in alkali chloride melts was determined from the results of electrochemical measurements:

$$
\begin{array}{rll}
\Delta G_{M o C l 3(\text { melt })} & =\left(-483,5+228,3 \cdot 10^{-3} T\right) \pm 3 \mathrm{~kJ} / \mathrm{mol} & (\mathrm{NaCl}-\mathrm{CsCl}) \\
\Delta G_{M o C l 3(\text { melt })} & =\left(-384,2+129,2 \cdot 10^{-3} \mathrm{~T}\right) \pm 4 \mathrm{~kJ} / \mathrm{mol} & (\mathrm{NaCl}-\mathrm{KCl}) \\
\Delta G_{\text {MoCl3(melt) }} & =\left(-368,8+148,9 \cdot 10^{-3} \mathrm{~T}\right) \pm 4 \mathrm{~kJ} / \mathrm{mol} & (\mathrm{LiCl}-\mathrm{KCl}-\mathrm{CsCl})
\end{array}
$$

1. Selies S. M., J. Electrochem. Soc. 113, 37 (1966).

2. Baraboshkin A. N., Valeev Z. I., Talanova M. I. and Martem'yanova Z. S., Trans. Int. Electrochem. 23, 52 (1976) (in Russian).

3. Vasin B. D., Ivanov V. A., Shulman I. V. and Raspopin S. P., Izv. Vuzov, Tsvet. Metal. (2), 68 (1987) (in Russian). 